\title{
Regeneration of plants from callus cultures of roots induced by Agrobacterium rhizogenes on Alhagi pseudoalhagi
}

\author{
WANG Yu MeI ${ }^{1}$, JiAng Bo WANG ${ }^{2}$, DA LUO ${ }^{1}$, Jing Fen JIA ${ }^{2, *}$ \\ 1 National Laboratory of Plant Molecular Genetics, Institute of Plant Physiology and Ecology, Shanghai Institutes \\ for Biological Sciences, Chinese Academy of Sciences, Shanghai 200032, China \\ 2 Department of Biology, Northwest University, Xi'an 710069, China
}

\begin{abstract}
The legume forage Alhagi pseudoalhagi was transformed by the Agrobacterium rhizogenes strain A4 using cotyledon and hypocotyl segments as infection materials. Plant regeneration was achieved from sterile calluses derived from hairy roots, which occurred at or near the infection sites. The hairy root regenerants were characterized by normal leaf morphology and stem growth but a shallow and more extensive root system than normal plants. Opine synthesis, PCR and Southern blot confirmed that T-DNA had been intergrated into the A. pseudoalhagi genome. Acetosyringone (AS) was found to be vital for successful transformation of A. pseudoalhagi.
\end{abstract}

Key words: Alhagi pseudoalhagi, Agrobacterium rhizogenes, hairy root, regeneration.

\section{INTRODUCTION}

The hairy root disease is a pathological syndrome of dicotyledonous plants following wounding and infection with Agrobacterium rhizogenes[1]. The rhizogenicity is conferred to plant cells by a fragment of DNA (Ri T-DNA), which is transferred from the large root-inducting $(\mathrm{Ri})$ plasmid, harboured by the bacterium, to the genome, where it is stably integrated and expressed. Integration of a DNA segment (T-DNA) of $\mathrm{pRi}$ into the host genome leads to active proliferation of adventitious roots (hairy roots) at or near the site of infection[2],[3]. If the A. rhizogenes containing modified Ri plasmid is used to infect plant cells, it is possible to transfer the target genes to plant tissues and to induce regeneration of transgenic plants. Therefore, $A$. rhizogenes can be used in genetic manipulation of higher plants for improving plant resistance, quality, and possible

* Corresponding author: Jia Jingfen, Department of Biology, Northwest University, Xi' an 710069, China

Abbreviations: 6-BA=Benzyladenine; 2,4- $\mathrm{d}=2$, 4-dichlorophenoxyacetic; IAA =3-Indolylacetic acid; IBA=Indole-3-butyric acid; NAA $=a$-Naphthaleneacetic acid.Received July-8-2001 Revised Sept-27-2001 Accepted Oct-25-2001 utilization. Many reports about hairy root transformation of forage legume have been published, including alfalfa[4], common Sainfoin ( Onobrychis viciaefolia)[5] and model legume Lotus japonicus[6]. However, A. rhizogenes mediated transformation of Alhagi pseudoalhagi has not been reported yet. A. pseudoalhagi is a herbaceous perennial species mainly distributed in China, Mongolia and Russia. Because of its tolerance to drought, frost, sandstorm and salinity, it is widely cultivated in China as a highly palatable forage. A. pseudoalhagi is among the few forages and legumes that can be regenerated relatively easily from tissue culture[7].

In this paper we present transformation of $\mathrm{A}$. pseudoalhagi by A. rhizogenes strains A4. Transgenic plants were confirmed by opine synthesis and T-DNA analysis. Phenotypic alterations, mainly of the root system, were observed in transformed plants.

Acetosyringone (AS) is a phenolic compound released by wounded cells of some dicotyledonous plant[8]. It plays an important role in the natural infection of plants by A. rhizogenes as it activates 
the virulence genes of the Ri plasmid which initiates transfer of the T-DNA region to the plant DNA. Therefore, AS has been widely used in experiments aimed at increasing $\mathrm{Ri}$ transformation frequencies [9-12]. Here we report that treatment of $\mathrm{A}$. rhizogenes with $100 \mu \mathrm{M}$ AS prior to incubation with cotyledon and hypocotyl segments leads to a remarkable increase of hairy root formation of $\mathrm{A}$. pseudoalhagi. The high rates of transformation and the relatively simple and efficient procedures for regenerating fertile plants suggest that this method for A. pseudoalhagi transformation is an efficient genetic transformation system.

\section{MATERIALS AND METHODS}

\section{Activation of bacterial strain}

A. rhizogenes wild-type strain A4 stored at $4 \mathrm{oC}$ were transferred to agar-solidified YMB medium[13] and cultured at $25^{\circ} \mathrm{C}$ in the dark. A single bacterial colony was inoculated into $10 \mathrm{ml}$ liquid YMB medium in the presence or absence of $100 \mu \mathrm{M}$ AS (acetosyringone) and cultured at $28^{\circ} \mathrm{C}$ for $24 \mathrm{~h}$ in the dark on a shaker agitated at $120 \mathrm{rpm}$. The bacterial suspension was centrifuged for $10 \mathrm{~min}$ at $4000 \mathrm{rpm}$ and the collected bacteria were resuspended in $10 \mathrm{ml}$ of hormone-free MS[14] liquid medium with an O.D600 value adjusted to $0.6-0.8$ at $600 \mathrm{~nm}$.

\section{Hairy root induction, culture and plant regeneration}

Mature seeds of A. pseudoalhagi were obtained from Lanzhou Institute of Desert Research, Chinese Academy of Sciences. The seeds of A. pseudoalhagi were immersed in $70 \%$ ethanol for 30 sec, surface-sterilized in $0.1 \% \mathrm{HgCl}_{2}$ for $8-10 \mathrm{~min}$,followed by five rinses with sterile distilled water and then germinated on hormone-free $\mathrm{MS}$ medium at $24^{\circ} \mathrm{C} \pm 2^{\circ} \mathrm{C}$ under lamps (approximately $30 \mathrm{~mm}^{-2} \mathrm{~s}^{-}$ ${ }^{1}, 16 \mathrm{~h}$ photoperiod). Cotyledon and hypocotyl segements (approximately $1 \mathrm{~cm}$ length) of 10 to 15-day-old aseptically-grown seedings were used as explants. Explants were dipped into bacterium suspension for $1 \mathrm{~h}$. After blotting dry, they were transferred to hormone-free MS medium and co-cultured for 2 days, then rinsed 5 times in sterile distilled water and subcultured on hormone-free MS medium containing $500 \mathrm{mg} / \mathrm{L}$ cefotaxime. Cefotaxime concentration was gradually reduced to $250 \mathrm{mg} / \mathrm{L}$, $100 \mathrm{mg} / \mathrm{L}$ with each subculture. Hairy roots derived from explants were placed on MS medium supplemented with $2.0 \mathrm{mg} / \mathrm{L} \mathrm{2}$, 4-D and $0.5 \mathrm{mg} / \mathrm{L} 6$-BA for 4 weeks to induce callus. Shoots were regenerated after 3 weeks on $\mathrm{MS}$ medium with $3 \mathrm{mg} / \mathrm{L} 6$-BA. The developed shoots were cultured on MS medium with $2 \mathrm{mg} / \mathrm{L} \mathrm{IAA}$, $2 \mathrm{mg} / \mathrm{L} \mathrm{NAA}$ and $2 \mathrm{mg} / \mathrm{L}$ IBA to induce root system. The culture conditions in growth chamber were $24^{\circ} \mathrm{C} \pm 2^{\circ} \mathrm{C}, 16 / 8$ photoperiod under $60 \mu \mathrm{m} \mathrm{m}^{-2} \mathrm{~s}^{-1}$ light intensity.

\section{Opine assay}

For the detection of opine in the primary hairy roots, the secondary hairy roots, the calli derived from hairy roots and the leaves of regenerated plantlets transformed, 100-200 mg fresh weight of tissue were transferred to a sterile Eppendorf tube and macerated with a plastic rod. After centrifugation for $15 \mathrm{~min}$ in a MSE micro-centrifuge, $10 \mu \mathrm{l}$ were spotted on Whatman $3 \mathrm{MM}$ chromatography paper and dried. Electrophoresis was at $45 \mathrm{~V} / \mathrm{cm}$ for $30 \mathrm{~min}$ in formic acid-acetic acid-water (30:60:910, v/v/v) at $\mathrm{pH}$ 2.1. The dried papers were stained with silver nitrate as described by Petit et al[15], dipped in photographic fixer and washed for several hours with running water. The dried papers were viewed and photographed under UV. light (254 nm).

\section{PCR analysis}

Plant DNA for polymerase chain reaction (PCR) analysis was extracted as described by Edwards[16]. The tissue (50mg fresh weight) was homogenized in $200 \mu$ l of extraction buffer (0.5\% SDS, $250 \mathrm{~m} \mathrm{M} \mathrm{NaCl}, 100 \mathrm{~m}$ M Tris-HCl pH 8 and $25 \mathrm{~m} \mathrm{M} \mathrm{EDTA} \mathrm{pH} \mathrm{8)}$ and centrifuged at $14,000 \mathrm{rpm}$ for $5 \mathrm{~min}$. The supernatant was transferred to a new tube and an equal volume of isopropanol was added. The sample was incubated on ice for $5 \mathrm{~min}$ and then centrifuged for $10 \mathrm{~min}$ at $14,000 \mathrm{rpm}$. The pellet was dried at $60^{\circ} \mathrm{C}$ for 5 $10 \mathrm{~min}$ and then resuspended in $100 \mu \mathrm{l}$ of $\mathrm{TE}(10 \mathrm{~m} \mathrm{M}$ Tris- $\mathrm{HCl} \mathrm{pH}$ 7.4 and $1 \mathrm{~m} \mathrm{M} \mathrm{EDTA} \mathrm{pH} \mathrm{8).} \mathrm{The} \mathrm{rolB} \mathrm{gene} \mathrm{is} \mathrm{in} \mathrm{the} \mathrm{T-DNA} \mathrm{of} \mathrm{the}$ pRiA4 plasmid and transferred to the plant genome. It was detected in the plant and bacteriual nucleic acids by PCR using the procedure of Hamill et al[17]. For the rolB gene, the 5' primer was ATGGATCCCAAATTGCTATTCCTTCCACGA and the 3' primer was TTAGGCTTCTTTCTTCAGGTTTACTGCAGC. These primers amplified a 780-bp fragment. The PCR reactions were carried out in a total volume of $30 \mathrm{ml}, 1 \mu \mathrm{l}$ samples of $\mathrm{A}$. pseudoalhagi genemic DNA, 20 pmol of each primer, $200 \mu \mathrm{M}$ each dNTP, 0.5 units Taq DNA polymerase and $3 \mu \mathrm{l} 10 \times$ PCR buffer. Cycling conditions were: denaturation at $94^{\circ} \mathrm{C}$ for $1 \mathrm{~min}$, annealing at $55^{\circ} \mathrm{C}$ for $1 \mathrm{~min}$ and extension at $72^{\circ} \mathrm{C}$ for $3 \mathrm{~min}$. Samples were subjected to 30 cycles. Amplification products were analyzed by electrophoresis on $0.8 \%$ agarose gels and detected straining with ethidium bromide.

\section{Southern blot hybridization}

Genomic DNA from transformed and non-transformed soilgrown plants were extracted using the CTAB extraction method according to Rogers[18]. Approximately $10 \mathrm{mg}$ of DNA from each sample were digested with HindIII, BamHI, EcoRI, respectively, non-transformed plant was digested with EcoRI, then separated by electrophoresis $0.8 \%(\mathrm{w} / \mathrm{v})$ agarose gel, transferred from the agarose gel to Hybond ${ }^{+}$nylon membrane and cross-linked to the membrane by UV light for $3 \mathrm{~min}$. Probe were labeled with a $32 \mathrm{P}$ labeled probe specific to the coding sequence of the introduced rolB gene for Southern hybridization. Filters were pre-hybridized in $5 \times \mathrm{SSC}, 5 \times$ Denhardt's solution, $0.5 \% \mathrm{SDS}, 20 \mu \mathrm{g} / \mathrm{ml}$ denatured salmon sperm DNA at $65^{\circ} \mathrm{C}$ and subsequently hybridized overnight with labeled probe. After stringent washing $(0.1 \times \mathrm{SSC}, 0$. $1 \% \mathrm{SDS}, 65^{\circ} \mathrm{C}$ ) filters were autoradiographed at $-70^{\circ} \mathrm{C}$ for 3 days with an intensifying screen. 


\section{RESULTS AND DISCUSSION}

\section{Phenotype of transgenic plants}

After inoculating cotyledon and hypocotyl segments of A. pseudoalhagi with wild type A. rhizogenes strain A4 on hormone-free MS medium, numerous hairy roots appeared on the infection sites in 10 days. Elongating root tips were cut off and transferred onto cefotaxime supplemented MS medium until no colony of bacteria appeared. Axenic hairy roots grew rapidly independent of hormone and exhibited extensive lateral branching (Fig 1), which were typical hairy root phenotypes. Non- infected explants became necrotic gradually and could not form hairy roots, whether or not treated with AS. The hairy root-derived calli were yellowishbrown, friable and growing slowly on callus induction medium. When the calli were transferred to the regeneration medium, they underwent differentiation. This process started with an intense browning of the tissue and resulted in the development of small shoots within three weeks (Fig 2). After three weeks, the elongated shoots were transferred onto root induction medium and the root system formed. Individual roots were distinctively strong and showed a marked development of lateral branching in comparing with normal plants (Fig 3). The leaves of transformed regenerants were normal and exhibited no crinkling as previously reported for those hairy root-derived plants[19],[20]. Tepfer [21] proposed that Ri T-DNA might be used to improve the rooting ability of root stocks or to create root systems that are better adapted to environmental stress, e.g., drought. This is consistent with our goal of altering rooting ability and the root system morphology in A. pseudoalhagi. Hopefully, these characteristics may help A. pseudoalhagi to overcome environmental constraints such as lack of water. Moreover, the nitrogen fixation of legume plants may be improved by strong root system resulted from $\mathrm{Ri}$ T-DNA transformation, therefore, choosing legume plants as the material of A. rhizogenes infection could be of great agronomic potential.

nsertion of Ri T-DNA is known to affect plant phenotype, including reduced height and increased rooting ability. Genetic transformation of Astragalus sinicus by the A. rhizogenes strain DC-AR2 produced plants with phenotypes of smaller and thin leaves, reduced plant height, and altered root morphology with irregularly branched fine masses exhibiting negative genotropism. There was, however, no correlation between the morphological variation of leaves from individual transformed plants and the intensities of hybridization signals probed with the rolABC gene[22]. Tanaka Reported that regenerants derived from hairy roots of Ajuga repans var atropurpurea[23] and Vinca minor L[24] induced by infection with A. Rhizogene were similarly dwarf in stature. However, the M. Sativa plants transformed with A. rhizogenes strain A4 were phenotypically normal except for extensive and shallow roots[25]. Tabaeizadeh[26] reported that regenerated Lotus corniculatus plants transformed with wild-type A. rhizogenes showed no morphological difference with respect to leaf shape or plant height when compared to seed grown plants.
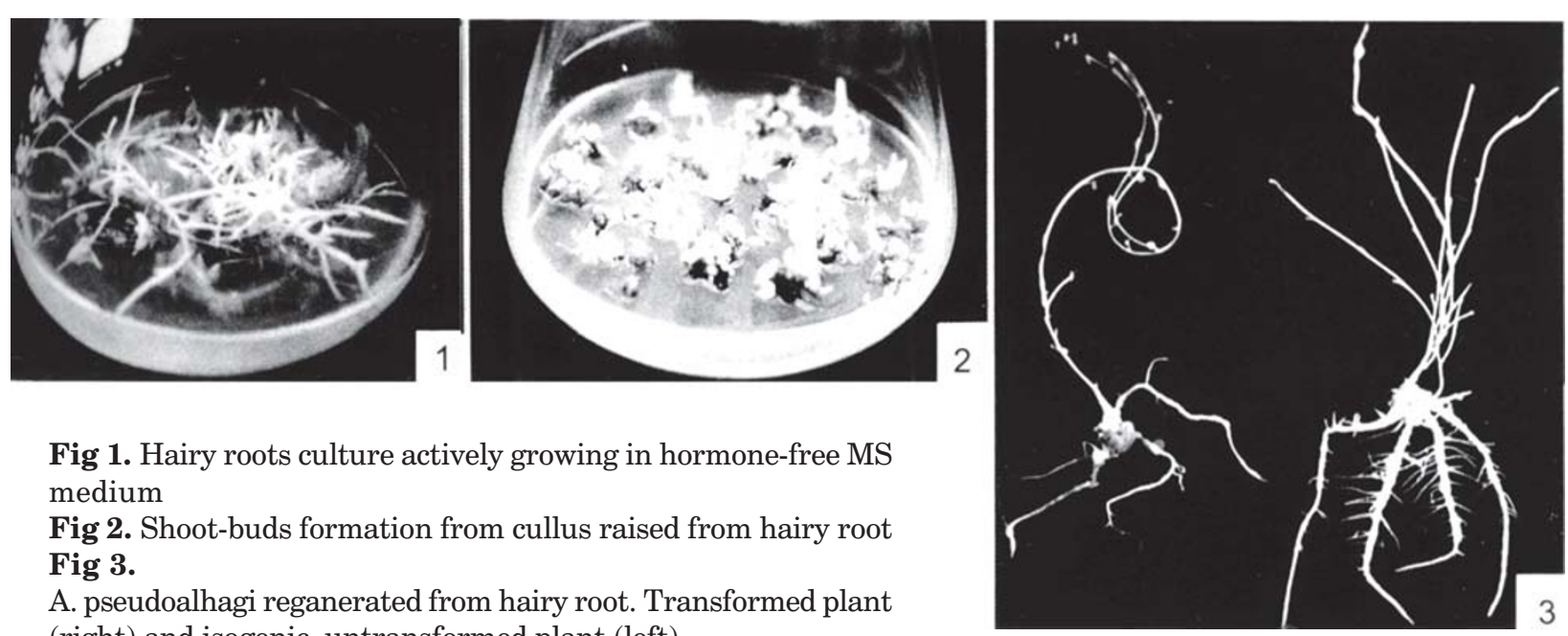

Fig 1. Hairy roots culture actively growing in hormone-free MS medium

Fig 2. Shoot-buds formation from cullus raised from hairy root Fig 3.

A. pseudoalhagi reganerated from hairy root. Transformed plant (right) and isogenic, untransformed plant (left). 


\section{Opine analysis}

Agropine and mannopine are well known opines detectable in hairy roots transformed with Ri plasmid[27]. In our experiment, the presence of agropine and mannopine was analysed by paper electrophoresis followed by alkaline silver nitrate staining. Both agropine and mannopine were detected in extract of the primary hairy roots, the secondary hairy roots, the calli derived from hairy roots and the leaves of regenerated plantlets transformed by A. rhizogenes strain A4 (Fig 4).

\section{Effect of different explants on induction of hairy roots}

Within 10 days after inoculation with A. rhizogenes strains A4, an average of 20-30 hairy roots were developed from each wound site on the cotyledon, while only 2-8 hairy roots per hypocotyl could be induced, even if the culture time was over

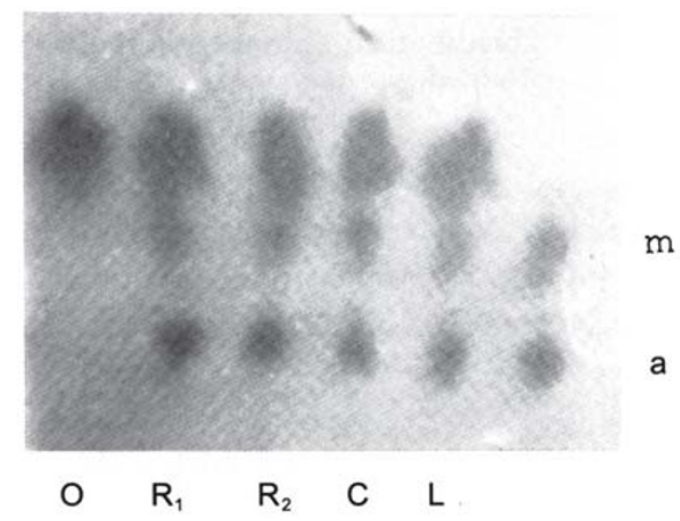

Fig 4. Paper electrophoretic analysis of extracts from hairy root cultures of $\mathrm{A}$. pseudoalhagi. $\mathrm{O}$ : contral calli; $\mathrm{R}_{1}$ : primary hairy roots; $\mathrm{R}_{2}$ : secondary hairy roots; $\mathrm{C}$ : calli derived from hairy roots; L: leaves of regenerated plantlets. a: agropine; $\mathrm{m}$ : mannopine twenty days. This result showed that the induction of hairy roots from the cotyledon was easier than that from the hypocotyl of A. pseudoalhagi. This could be probably explained by several points. First, the cut area of the cotyledon might induce more attachment of bacterium as it was larger than that of the hypocotyl. Second, because of the differences in physiologial conditions, the susceptibility of explants to A. rhizogenes was diverse in different tissues of the same plant[28]. Third, compared with the hypocotyl, the cotyledon of A. Pseudoalgagi dedifferentiated easily into callus in tissue culture, probably due to cell divisions in cotyledon segments started earlier than in hypocotyl after wounding. The possible correlation of cell division with maximal transformation suggested that cell division and/or DNA synthesis might be important to the process of transformation[29].

\section{Effect of $A S$ on transformation}

To test the effect of AS on A. pseudoalhagi transformation, $100 \mu \mathrm{M}$ AS was added to A. rhizogenes cultures $16 \mathrm{~h}$ prior to exposure of explants to the bacteria. Tab 1 showed that the transformation frequencies ranged from 59.2 to 84.7 percent when AS was added into A. rhizogenes cultures prior to incubation with cotyledon and hypocotyl, while it was only 10.6 to 22.4 percent if AS was not supplemented. This result indicated that AS was a key factor that contributed to the high rates of transformation of A. pseudoalhagi. The low rate of hairy root transformation in A. pseudoalhagi without AS pretreatment suggested that natural exudates of wounded A. pseudoalhagi may be sufficient to elicit some Vir region activity, but AS treatment may

Tab 1. Frequencies of hairy roots from Alhagi pseudoalhagi cotyledon and hypocotyl explants induced by Agrobacterium rhizogenes strain A4

\begin{tabular}{cccccccc}
\hline $\begin{array}{c}\text { Bacterium } \\
\text { strains }\end{array}$ & Explants & $\begin{array}{c}\text { No. of } \\
\text { explants }\end{array}$ & $\begin{array}{c}\text { In the absence of AS } \\
\text { explants forming } \\
\text { hairy roots }\end{array}$ & $\begin{array}{c}\text { Hairy roots } \\
\text { formation (\%) }\end{array}$ & $\begin{array}{c}\text { No. of } \\
\text { explants }\end{array}$ & $\begin{array}{c}\text { No. of } \\
\text { explants forming } \\
\text { hairy roots }\end{array}$ & $\begin{array}{c}\text { Hairy roots } \\
\text { formation (\%) }\end{array}$ \\
\hline Control & Cotyledon & 135 & 0 & 0 & 144 & 0 & 0 \\
& Hypocotyl & 113 & 0 & 0 & 130 & 0 & 0 \\
\hline A4 & Cotyledon & 125 & 128 & 22.4 & 138 & 117 & 84.7 \\
& Hypocotyl & 165 & 22 & 13.3 & 180 & 111 & 61.7 \\
\hline
\end{tabular}


stimulate the bacterium to transfer T-DNA to host cells more efficiently. Consequently, AS treatment of A. rhizogenes might be useful in improving transformation rates of other plant species which were recalcitrant to be transformed.

\section{DNA analysis}

The presence of the rolB gene in the transformed plants was confirmed by PCR analysis (Fig 5). In this work, the positive results obtained in the amplification of the rolB gene in the transformed plants

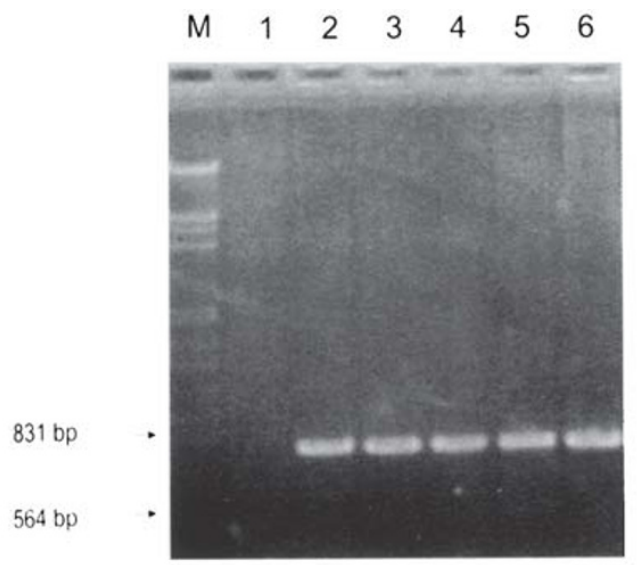

Fig 5. PCR detection of the rolB gene in transgenic A. pseudoalhagi roots and plants by pRiA4. M: $\lambda$-DNA (HindIII+EcoRI digest); 1 . DNA from non-transformed plant; 2-5. DNA from primary hairy roots, secondary hairy roots, calli derived from hairy roots, leaves of regenerated plantlets transformed; 6.plasmid DNA of pRiA4

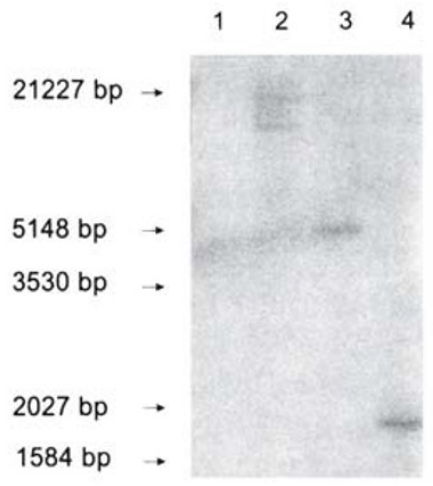

Fig 6. Southern blot analysis of DNA samples isolated from transformed and non-transformed A. pseudoalhagi plants by pRiA4, probe with ${ }^{32} \mathrm{P}$-Clabeled rolB. Genomic DNA extracted from transformed and non-transformed A. pseudoalhagi cells was digested with restriction endonucleases and the fragments were separated by electrophoresis and transferred to Hybond+ nylon membrane. M: $\lambda$-DNA (HindIII+EcoRI digest). Line 1 is EcoRI digest of non-transformed DNA and lane 2-4 digests of transformed DNA. Lane 2, BamHI; Lane 3, EcoRI; Lane 4, HindIII. can be attributed to true transformation events rather than to residual Agrobacterium. For the Southern blot analysis (Fig 6), DNA were extracted from one non-transformed plant and one transformed plant. The probe hybridized with DNA from the nontransformed plant did not show any hybridization signal. The pattern of rolB specific probe hybridized to DNA fragments from BamHI, EcoRI and HindIII digests suggested that the rolB gene and one copy of pRiA4 had been integrated into A. pseudoalhagi genome.

Roots from regenerated plants derived from calli of hairy roots were much more adventitious and stronger than roots from non-transgenic regenerated plants. Methods of Ri T-DNA transformation established in this study could be used to develop transgenic plant of agronomically important A. pseudoalhagi cultivars with resistance to environment stress such as drought. It should be pointed out that a major interest in the transformation study is due to the possibilities in genetic manipulation of plant cells offered by the system. Therefore, further work, including expression of transgenes in A. pseudoalhagi to create new genotypes and phenotypes in A. pseudoalhagi breeding, is feasible.

\section{ACKNOWLEDGEMENTS}

We express our sincere thanks to Lanzhou Institute of Desert Research, Chinese Academy of Sciences, for generously supplying mature seeds of A. pseudoalhagi. This research was supported by National Natural Science Foundation (No. 30070366).

\section{REFERENCES}

[1] Elliot C. "Manual of Bacterial Plant Pathogens " 2nd (rev.) cad. (Chronica Botanica: Waltham, Mass.) 1951.

[2] Chitton MD, Tepfer DA, Petit A. Agrobacterium rhizogenes inserts T-DNA into the genome of host plant root cells. Nature 1982; 295:432-4.

[3] White FF, Ghidossi G, Gordon MP. Tumor induction by Agrobacterium rhizogenes involves the transfer of plasmid DNA to the plant genome. Proc Natl Acad Sci USA 1982; 79:193-7.

[4] Spano L, Mariotti D, Pezzotti M. Hairy root transformation in alfalfa ( Medicago sativa L). Theor Appl Genet 1987; 73: 523-30.

[5] Xu ZQ, and Jia JF. Transformation of Onobrychis viciaefolia hypocotyl with Agrobacterium rhizogenes A4 and plant regeneration. J Lanzhou Univ (Nat Sci) 1994; 3(2):96100.

[6] Stiller-J, Martirani-L, Tuppale-S. High frequency trans- 
formation and regeneration of transgenic plants in the model legume Lotus japonicus. Journal of Experimental Botany 1997; 48(312):1357-65.

[7] Shashi Bharal and Rashid A. Tisseu culture of Alhagi camelorum-a legum of high regenrative capacity Physiol Plant 1981; 53:497-500.

[8] Stachel SE, Messens E, Van Montagu M. Identification of the signal molecules produced by wounded plant cells that activate T-DNA transfer in Agrobacterium tumefaciens. Nature 1985; 318:625-9.

[9] Webb KJ, Gibbs MJ, Mizen S. Genetic transformation of Lotus corniculatus with Agrobacterium tumefaciens and the analysis of the inheritance of transgenes in the T-1 generation. Transgenic Research 1996; 5(5):303-12.

[10] Hao GX, Zhu Z, Zhu ZT. Study on optimization of transformation of Populus tomentosa. Acta-Botanica-Sinica 1999; 41(9):936-40.

[11] Nadolska-Orczyk-Anna. Study of the factors influencing Agrobacterium-mediated transformation of pea ( Pisum sativum L). Orczyk-Waclaw Molecular-Breeding 2000; 6 (2):185-94.

[12] Huang JQ, Wei ZM, An HL, Zhu YX. Agrobacterium tumefacien-mediated transformation of rice with the spider insecticidal gene conferring resistance to leaffolder and striped stem borer. Cell Research 2001; 11(2):14955 .

[13] Hooykaas PJJ, Klapwijk PM, Nuti MP. Transfer of the Agrobacterium tumfaciens Ti plasmid to avirulent agrobacteria and to explanta. The Journal of General Microbiology 1977; 98:477-84.

[14] Murashige T. Skoog F. Revised media for rapid growth and bioassays with tobacco tissue culture. Physiologia Plantarum 1962; 15:473-79.

[15] Petit A, David C, Dahl GA. Futher extension of the opine concept: plasmids in Agrobacterium rhizogenes cooperate for opine degradation. Molecular and Genetics 1983; 190:204-14.

[16] Edwards K, Johnstone C, Thompson C. A simple and rapid method for the preparation of plant genomic DNA for PCR analysis. Nucleic Acids Res 1991; 19:1349.

[17] Hamill JD, Rounsley S, Spencer A. The use of the poly- merase chain reaction in plant transformation studies. Plant Cell Rep 1991; 10:221-4.

[18] Rogers SO. Bendich AJ. Extraction of DNA from milligram amounts of fresh herbarium and mummified plant tissues, Plant Mol Biol 1985; 5:69-76.

[19] Kitisri Sukhapinda, Rosa Spivey, Elias A. Shahio. Riplasmid as a helper for introducing vector DNA into alfalfa plants. Plant Molecular Biology. 1987; 8:209-16.

[20] Ooma G, Karp A, Burrell M, Twell D, Roberts J. Genetic modification of potato development using Ri T-DNA. Theor Appl Genet 1985; 70:440-6.

[21] Tepfer D. Transformation of several species of higher plants by Agrobacterium rhizogenes: sexual transmission of the transformed genotype and phenotype. Cell 1984; 37:959- 67.

[22] Cho HJ, Widholm J M, Tanaka N, Nakanishi Y, Murooka Y, Agrobacterium rhizogenes-mediated transformation and regeneration of the legume Astragalus sinicus (Chinese milk vetch). Plant Science 1998; 138:53-65.

[23] Tanaka N, Matsumoto T. Characterixation of Ajuga plants regenerated from hairy roots, Plant Tissue Culture Lett 1993; 10:78-83.

[24] Tanaka N, Takao M, Matsumoto T. Agrobacterium rhizogenes-mediated transformation and regeneration of Vinca minor L, Plant Tissue Culture Lett. 1994; 11: 191-8.

[25] Sukhapinda K, Spivey K, Shahin EA, Ri-plasmid as a helper for introducing vector DNA into alfalfa plants. Plant Mol Biol 1987; 8:209-16.

[26] Tabaeizadeh Z, Genetic transformation of a pasture legume, Lotus corniculatus, L. (Birdsfoot trefoli). Biotechnol Lett 1989; 11:411-6.

[27] Petit A, David C, Dahl GA. Futher extension of the opine concept: plasmids in Agrobacterium rhizogenes cooperate for opine degradation. Molecular and Genetics 1983; 190:204-14.

[28] Xu XL, Liu WH, Li JL. Using Ri-plasmid to Transfer Tomato Primarily. Biotechnology 1993; 3(1):20-4.

[29] Braun A.C. The cell cycle and tumorgenesis in plants. Results Probl Cell Differ 1975; 7:177-96. 